\title{
The Link between HR Attributions and Employees' Turnover Intentions
}

\author{
Juliana Caesaria Tandung \\ PetraChristian University, Surabaya
}

\begin{abstract}
Human Resources Management (HRM) is part of the organizational functions that contribute to the effectiveness of a firm's performance, and brings an organization a competitive advantage through the implementation of its Human Resources (HR) practices. HR practices adopted by management are perceived or attributed subjectively by individual employees, and can in turn affect the employees' attitudes and behavior (e.g. Job satisfaction and turnover intention). The purpose of this study is to contribute to the process-based approach by investigating the effect of HR attributions on turnover intentions, with job satisfaction playing a mediating role. The analysis is on the individual level, with 454 respondents from various organizations within the Netherlands. The results show that HR attributions can affect the turnover intention, through the presence of job satisfaction. Thus, it can be said that it is important to always consider the employees' attitudes and behavior when examining their perception of HR practices, and in predicting their intention to leave.
\end{abstract}

\begin{abstract}
Abstrak: Manajemen sumber daya manusia (MSDM) adalah bagian fungsi organisasi yang berkontribusi pada keefektifan kinerja perusahaan dan juga merupakan sumber keunggulan kompetitif organisasi yang dicapai melalui implementasi praktik-praktik pengelolaan sumber daya manusia (SDM). Berbagai praktik pengelolaan SDM yang diadopsi oleh manajemen dipersepsikan atau diatribusikan secara subjektif oleh para karyawan, dan selanjutnya hal ini dapat mempengaruhi sikap dan perilaku karyaw an (misalnya: kepuasan kerja dan intensi untuk keluar). Penelitian ini bertujuan untuk berkontribusi pada pendekatan berbasis proses dengan menginvestigasi efek atribusi SDM terhadap intensi keluar, dengan menggunakan kepuasan kerja sebagai variabel pemediasi. Analisis penelitian ini dilakukan pada tingkat individual dengan menggunakan 454 responden yang bekerja pada berbagai perusahaan di Belanda yang bergerak di beragam sektor industri. Hasil penelitian menunjuk kan bahwa atribusi SDM mempengaruhi intensi untuk keluar dari perusahaan, hanya jika hubungan tersebut dimediasi oleh kepuasan kerja. Oleh karena itu, sangat penting untuk mempertimbangkan sikap dan perilaku karyawan, ketika menganalisa bagaimana persepsi mereka terhadap praktik-praktik pengelolaan SDM, dan memprediksi intensi mereka untuk keluar dari perusahaan.
\end{abstract}

Keywords: HR attributions; job satisfaction; turnover intention

JEL classification: L2

* Corresponding author's e-mail: caesaria@petra.ac.id 


\section{Introduction}

It is now well established that Human Resources Management (HRM) has many positive impacts on the competitive advantage of organizations (Wright, McMahan, and McWilliams 1994; Boselie and Wiele 2002). Although there is some evidence that HR interventions affect organizational performance (e.g. Subramony 2009), there is still a limited understanding of the process of how HRM contributes to firms' performance (Guest 2011). The content-based approach and the process-based approach are discussed the most by researchers to explain the link between HRM and organizational performance (Bowen and Ostroff 2004; Chen and Wang 2014; Sanders and Yang 2015): The content-based approach focuses on the implementation of a set of HR practices to achieve the organization's strategic goals, whereas the process-based approach focuses on the psychological process through which employees attach meaning to the HR practices adopted by their management to reach the organizational goals. Although the latter has recently received an increasing importance from researchers to solve the HRM-performance link, insight into this process is still limited (Piening et al. 2014).

The process-based approach is grounded in the attribution theory by Kelley (1967) which addressed the causal explanations people make on social events and outcomes. In an organizational context, this means employees can perceive or attribute the implementation of HR practices subjectively and in different ways. The concept of HR attributions was first introduced by Nishii et al. in 2008 and have been studied by only a few researchers so far (e.g. Fontinha et al. 2012; Chen and Wang 2014; Sanders and Yang 2015). HR attributions refer to the employees' causal explanation or perception of why certain HR practices are adopted by the management within their organization. Employees may perceive that HR practices (e.g. training and development) are adopted to enhance their well-being, while on the other hand, they might perceive it is for the reason of employee exploitation.

Despite the recognized increasing importance of the psychological process to explain the HRM-performance link, on the other side of the coin, van Buren III et al. (2011) raised concerns that the role of HRM had shifted to a strategy focus -focusing on accomplishing goals that are valuable to the organization - at the expense of an employee focus; meaning that the focus is more on the organizational needs rather than the employee needs. This results in the employees' view that organizations are not prioritizing their employees' well-being, but on the other hand are only using them for the organization's economic means.

A number of studies have stressed the desired attitudinal and behavioral reaction to HR practices, such as high satisfaction. Increased satisfaction is one of the desired employee responses to HR practices (Arthur 1992, 1994; Huselid 1995; Jackson and Schuler 1995; Tsui et al. 1997), as it is believed that "Happy employees are productive employees." Employee satisfaction depends on how the HR practices are perceived and interpreted by the employees, while the employees' perception relies on how the HR practices may help the individuals in accomplishing their personal goals and in satisfying their needs (Locke 1976; Vroom 1966). Even though there is evidence that employees' perceptions influence an employee's attitude and behavior (Nishii et al. 2008), little attention has been paid to the employees' attribution of why certain HR practices exist. Kelley and Michela (1980) pointed out that understand- 
ing these attributions is essential as these can help predict employees' future attitudes and behavior which will ultimately affect the organizational perfor mance (Nishii et al. 2008).

Taking a step further, Kim (2012) mentioned that retention or a reduction in voluntary turnover has been a major concern for HR managers as organizations stress the importance of organizational performance and employee productivity. Moreover, several studies that have researched the causes of voluntary turnover have mentioned that perceptions of HR practices as well as job satisfaction are one of the determinants of voluntary turnover.

This present study will analyze the relationship of HR attributions and turnover intention through the mediating role of job satisfaction. The aim is to contribute to the process-based approach by showing the importance of employees' perceptions through further elaboration of the typologies of HR attributions introduced by Nishii et al. (2008).

\section{Literature Review}

\section{HR Attributions and Job Satisfaction}

The attribution theory has a long history and has been used by many scholars to study causal attributions (Nishii et al. 2008). Even so, Lord and Smith (1983) point out that researchers should be aware not to overgeneralize the attribution theory within organizational research, but instead to develop a more context specific attributional model. Hilton and Slugoski (1986) mentioned that although the attributional theory comes from the attribution theory, it is important to have a distinction between the two: the attribution theory addresses the cognitive reason- ing behind peoples' behavior in a general way, whereas the attributional theory is an application for a more specific field or context. In this research, HR practices can be considered as an example of the attributional theory, since the context is explicit and not general (Nishii et al. 2008).

According to Koys (1988, 1991), HR attributions can be classified into internal and external HR attributions. Internal attributions refer to whether the managements' adopted HR practices are derived "out of a spirit of justice" or "to attract and retain employees", whereas external attributions refer to whether the HR practices "encourage individual or organizational performance" or "to comply with government relations." Nishii et al. (2008) provided further development of these HR attributions by looking at the literature for Strategic Human Resources Management. They found that there are two additional themes that should be classified under the internal HR attributions: The first is related to the business or strategic goal that underlies the HR practices, the second is related to the employee-oriented philosophy that is adopted by management. Furthermore, each of these two internal attributions is differentiated by whether they result in positive (commitment-focused), or negative (controlfocused) connotations by the employees. Under the classification of business/strategic goals that underlie the HR practices, a commitment-focused connotation is labeled as a "service quality enhancement" (employees attribute that such HR practices are adopted by the management in order to enhance service quality), and a control-focused connotation is labeled as "cost reduction" (employees attribute that kind of HR practices are adopted by the management in order to reduce costs). In the classification of employee-oriented philosophy, a commit- 
Table 1. Typology of HR Attributions

\begin{tabular}{|c|c|c|c|}
\hline \multicolumn{4}{|c|}{ Typology of HR Attributions } \\
\hline & \multicolumn{2}{|c|}{ Internal Attributions } & \multirow[b]{2}{*}{$\begin{array}{c}\text { External } \\
\text { Attribution }\end{array}$} \\
\hline & $\begin{array}{c}\text { Business/Strategic } \\
\text { Goal Underlying HR }\end{array}$ & $\begin{array}{c}\text { Employee-Oriented } \\
\text { Philosophy }\end{array}$ & \\
\hline Commiment-focused & Service quality & Employee well-being & Union compliance \\
\hline Control-focused & Cost reduction & Exploiting employees & \\
\hline
\end{tabular}

Source: Nishiiet al. (2008)

ment-focused connotation is labeled as "employee well-being" (employees attribute that these HR practices are adopted by the management in order to promote employee wellbeing), and a control-focused connotation is labeled as "exploiting employees" (employees attribute that these HR practices are adopted by the management in order to exploit employees). Nishii's typolog y of HR attributions can be seen in Table 1 . The external attribution of 'union compliance' was not significant in Nishii et al. (2008), and so is excluded from the present work.

Job satisfaction is related to one's feelings (satisfied / dissatisfied) or a state-ofmind regarding the nature of one's work, which can be influenced by a variety of factors. According to Jones et al. (2009), job satisfaction is a factor that has received a lot of attention from economists and policy makers. Further, as Tsui et al. (1997) points out, one of the desired employee attitudes towards HR practices is high satisfaction, and in order to achieve this desired state, employees must perceive the HR practices positively. For example, if training is implemented by the organization to improve workforce utilization, employees will feel that their development is supported by the organization, thereby increasing job satisfaction (Jones et al. 2009;
Koster et al. 2009). This finding is consistent with the social exchange theory, which suggests that employees may feel the need to reciprocate when management provides some tangible benefit (Blau 1964): Employees possessing a positive perception of their firm's HR practices will feel a duty to respond in positive ways, which translates to higher levels of satisfaction (Boselie and Wiele 2001). This is also supported by Nishii et al. (2008), in a study containing considerable empirical depth: Respondents included 4,208 employees spread across 95 supermarket chains. Their study showed that the employees' perception towards the purpose of certain HR practices would influence their attitudes. Similar results were also seen in Fontinha et al (2012), with data derived from 158 outsourced IT workers in Portugal; and Sanders and Yang (2015) who did an experimental study with 354 employees from Dutch health care organizations.

Based on Nishii et al.'s (2008) study, the internal HR attributions "service quality" and "employee well-being" were positively related with employees' attitudes. As for the HR attributions "cost reduction" and "exploiting employees", these resulted in negative relationships with employees' attitudes. These results lead to the following hypotheses: 
$H_{10}$ : The internal HR attributions "service quality" and "employee well-being" will have a positive effect on the employees' job satisfaction.

$H_{16}$ : The internal HR attributions "cost reduction" and "exploiting employees" will have a negative effect on the employees' job satisfaction.

\section{HR Attributions and Turnover Intention}

Turnover is an important aspect for organizations because it is a determining factor of organizational effectiveness (Park et al. 1994). It is also important to note that turnover can be predicted through turnover intentions or the intention to leave (Jaros 1997; Vandenberg and Nelson 1999). According to Mitchel (1981), the turnover intention refers to the extent to which an employee plans to leave his/her job for another job inside or outside the organization. Moreover, as mentioned by Schwab (1991), valuable employees will leave an organization when they are able to find an external labor market with higher employability. Employee retention is therefore critical for the competitive advantage of organizations, as employee turnover rates can have significant negative consequences, such as a shortage in skilled workers.

Previous researches have shown that the employees' perception of HR practices can impact on employees' turnover intention. Kim (2012) who did a study of 789 state government IT employees in the United States found that employees that perceived fair opportunities for their advancement and promotion, and perceived organizational support for training and their development demonstrated lower turnover intentions. In another study which involved 350 professional work- ers in 20 Chinese service companies that are experiencing organizational changes, Chen and Wang (2014) examined the typologies of HR attribution by Nishii et al (2008); they found that the commitment-focused HR attribution had a negative direct effect towards the turnover intention as well as a negative indirect effect through the mediating role of the Perceived Organizational Support (POS). Control-focused HR attributions on the other hand had a positive indirect effect towards the turnover intention through POS. These results are also in line with the AttractionSelection-Attrition (ASA) model that states: Employees who react negatively to the HR practices of an organization will tend to leave the organization, and vice versa (Nishii and Wright 2007). This leads to the following hypotheses:

$H_{2 a^{\circ}}$ The internal HR attributions "service quality" and "employee well-being" will have a negative direct effect on the turnover intention.

$H_{2 b}$ : The internal HR attributions "cost reduction" and "exploiting employees" will have a positive direct effect on the turnover intention.

\section{Job Satisfaction as a Mediator between HR Attributions and Turnover Intentions}

Companies implement HR practices and policies for various purposes. No matter what the purpose, the employees' perceptions can vary widely. In other words, employees can and do attach different meanings to the motives behind certain HR practices. As Kelley and Michela (1980) mention, understanding how employees attach meaning or attribution to HR practices is important since this strongly influences the employees' behavior, which is critical to the firm (as is the case with job satisfaction). The more positively 
employees perceive certain HR practices, the more satisfied they will be (Boselie and Wiele 2001).

According to Bowen and Ostroff (2000) and Koster et al (2009), job satisfaction is one of the most researched work-related variables, and has a significant relationship with turnover intentions. An obvious reaction to dissatisfaction is to leave the company and change employers (Clark et al. 1998; De Moura et al. 2008; Mahdi et al. 2012), and conversely, employees who have high satisfaction levels are more motivated to stay within the company.

Several studies have proved the negative relationship of job satisfaction-turnover intention, as in the study by Wang et al. (2012) who analyzed 483 private and public sector employees in Taiwan; Mbah and Ikemefuna (2012) who analyzed 300 employees of To- tal Petrolium Nigeria PLC; and Saeed et al. (2014) who analyzed 166 public and private employees in Pakistan, who constituted both upper and lower level employees. This leads to the following hypotheses:

$H_{3 a}:$ Job satisfaction will have a negative effect on the turnover intention.

$H_{3 b^{\circ}}$ : The relationship between $H R$ attributions and the turnover intention is mediated by job satisfaction.

The overall conceptual model of this research is depicted in Figure 1. It is hypothesized that each HR attribution will have a positive or a negative influence on both the turnover intention and job satisfaction, whereas job satisfaction is hypo thesized to have a negative effect on the turnover intention. Finally it is predicted that job satisfaction will mediate the relationship between HR attributions and turnover intentions.

Figure 1. Conceptual Model

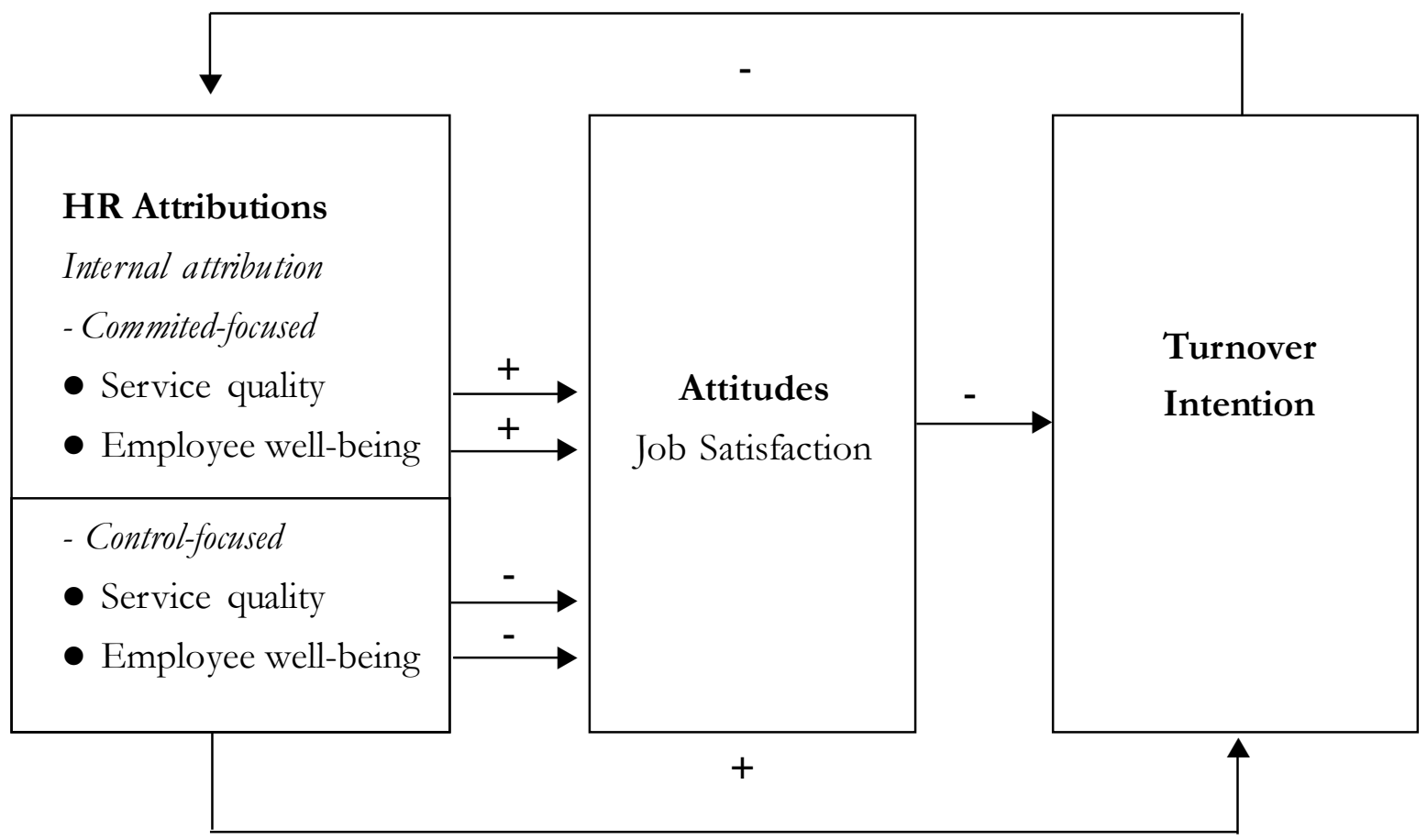




\section{Methods}

\section{Participants and Procedure}

Simple random sampling was used to gather 454 individual level data from employees who work in various organizations in the Netherlands, across numerous industries: Manufacturing, commercial services, government sectors, etc. The distribution by gender for this study is nearly even: 49.8 percent of the respondents are male. The mean age in the sample is 38.1 years (Standard Deviation $=11.4$, range 18 to 63 years). The educational level ranges from lower vocational education to university degrees, where a majority of the participants had higher vocational education qualifications $(39.2 \%)$ and vocational education qualifications $(33.3 \%)$. The average working hours per week are 33.7 hours, the average unit tenure (the duration an employee has been in the current unit/ division) is 6.39 years ( $\mathrm{SD}=6.99$; range: $\mathrm{A}$ few months to 38 years), and the average organizational tenure (the duration the employee has been with the current organization) is 9.83 years ( $\mathrm{SD}=9.91$; range: $\mathrm{A}$ few months to 42 years). Moreover, most of the participants $(80.3 \%)$ had a permanent employment contract with their organization.

\section{Measures}

$\boldsymbol{H R}$ attributions - Items used in the questionnaire were derived from existing scales, which established the validity of the constructs. Four HR attributions, namely service quality, employee well-being, cost reduction, and exploiting employees were measured using the construct by Nishii et al. (2008). Each of these HR attribution items were measured with each of the five HR practices, as in the study by Kroon et al. (2009): Selectivity in hiring, employee development and career opportunities, rewards, performance evaluation, and participation and communication. An example question is as follows: "This unit provides employees with the training that it does in order to help the employees deliver quality service to customers." The response categories range from 1 (not at all) to 5 (to a great extent) in which the responses indicate the extent to which employees perceive the relevantness of each HR attribution with respect to the HR practices implemented in their organization.

As in the study by Nishii et al. (2008), factor analysis was used to determine whether the attribution factors showed higher reliability when factored together. The results show the same conclusion: Internal HR attributions 'service quality' and 'employee wellbeing' showed a higher reliability when factored together, and so in this study, 'service quality' and 'employee well-being' are combined into the variable 'commitment focus' (Cronbach's $\alpha=0.847$ ). Consistent with the reasoning of Nishii et al. (2008), the result of a higher reliability when 'service quality' and 'employee well-being' are factored together can happen because these attributions share their same concern for people. Thus, when employees perceive that HR practices have been adopted in order to enhance the employees' service qualities, they will simultaneously perceive that they have been adopted to maximize the employees' well-being. The remaining two internal HR attributions - cost reduction and exploiting employees - also showed higher reliability when factored together, and are thus combined into the variable control focus (Cronbach's $\alpha=0.893$ ).

Job satisfaction - Spector (1997) distinguishes between the global approach and the facet approach of job satisfaction; the global approach measures the overall satisfaction one feels about one's job, whereas the facet approach measures the satisfaction to- 
wards a specific aspect/part of the job (e.g. rewards). Job satisfaction was measured using a combination of both the global approach and the facet approach with a Cronbach's $\alpha$ of 0.758 . The global approach was applied by using a single-item measure as in Wanous, Reichers, and Hudy (1997): "All things considered, I am satisfied with my job," with a measurement scale from 1 (strongly disagree) to 5 (strongly agree). The facet ap proach asked a more specific question regarding job satisfaction, "How satisfied are you with your rewards?," again using a 5-point Likert scale, 1 (very dissatisfied) to 5 (very satisfied).

Turnover intention- Turnover intention was measured using the 'intention to quit' scale by Colarelli (1984). The scale has a Cronbach's $\alpha$ of 0.805 , and consists of 3 items measured using a 5-point Likert scale ranging from 1 (strongly disagree) to 5 (strongly agree). An example question is "I am planning to search for a new job during the next 12 months."
Control variables - Gender, age, educational level, working hours per week, average unit tenure, average organizational tenure, and employees' contract type were controlled for in this research.

\section{Results and Discussion}

To test the hypothesis that job satisfaction mediates the relationship between HR attribution and turnover intention, the mediation test recommended by MacKinnon et al. (2007) was used. To test for mediation, two significant relationships are needed: 1) Between the independent variable (commitment focus and control focus) and the mediator variable (job satisfaction), and 2) between the mediator variable (job satisfaction) and the dependent variable (turnover intention). When both paths are statistically significant, there is evidence supporting mediation.

Table 2. Regression Analysis-Job Satisfaction

\begin{tabular}{lcccccccc}
\hline & \multicolumn{9}{c}{ Control Variables } & \multicolumn{5}{c}{ Step 1 } \\
\cline { 2 - 9 } & B & s.e & Beta & Sig & B & s.e & Beta & Sig \\
\hline Gender & .026 & .063 & .024 & .679 & -.052 & .051 & -.047 & .315 \\
Age & -.005 & .003 & -.114 & .102 & -.005 & .003 & -.113 & .046 \\
Education & .041 & .029 & .074 & .157 & .023 & .024 & .042 & .324 \\
Working hours (per week) & .003 & .004 & .046 & .426 & -.001 & .003 & -.009 & .854 \\
Unit Tenure & -.009 & .005 & -.111 & .090 & -.004 & .004 & -.050 & .349 \\
Organizational Tenure & .006 & .004 & .114 & .147 & .003 & .004 & .055 & .386 \\
Contract Type & -.011 & .048 & -.013 & .816 & -.034 & .039 & -.038 & .391 \\
Commitment Focus & & & & & .576 & .040 & .622 & .000 \\
Control Focus & & & & & -.195 & .033 & -.254 &. $\mathbf{0 0 0}$ \\
$\mathrm{R}^{2}$ & .026 & & & & .362 & & & \\
$\Delta$ R ${ }^{2}$ & .026 & & & & .336 & & & \\
F Value & 1.585 & & & & 25.611 & & & \\
\hline
\end{tabular}


The first step, an assessment of the direct relationship between the two independent variables (commitment focus and control focus) on the mediating variable (job satisfaction) after controlling for the seven control variables (gender, age, education, working hours per week, unit tenure, organizational tenure, and contract type) are shown in Table 2. The results show that after entering the two independent variables in the regression model, the total variance explained is 36 percent. The HR attribution of the commitment focus (beta $=0.622, \mathrm{p}<0.01$ ) shows a highly significant positive effect on job satisfaction, and the control focus (beta $=-0.254, \mathrm{p}<$ 0.01) shows a significant negative effect. Therefore Hypotheses $1 \mathrm{a}\left(\mathrm{H}_{1 \mathrm{a}}\right)$ and $\mathrm{H}_{1 \mathrm{~b}}$ are both confirmed.

The second step, the regression analysis for the turnover intention is shown below in Table 3. The independent variables commitment focus and control focus were hypothesized to have a direct effect on turnover intention, but as the job satisfaction variable is also entered into the model, the results indicate that the direct relationship is not significant. Thus Hypotheses $2 \mathrm{a}\left(\mathrm{H}_{2 \mathrm{a}}\right)$ and $\mathrm{H}_{2 \mathrm{~b}}$ are not supported. Moreover, it can be seen that job satisfaction (beta $=-0.492, \mathrm{p}<0.01$ ) has a significant negative effect on the turnover intention, confirming Hypothesis $3 \mathrm{a}\left(\mathrm{H}_{3 \mathrm{a}}\right)$.

As can be seen from the overall result, there is a significant effect of both the commitment focus and control focus on job satisfaction, and there is also a significant effect of job satisfaction on the turnover intention. Since there is no significant direct effect between the commitment focus and control focus on the turnover intention, the indirect effect can thus be estimated by multiplying the standardized coefficient between the commitment focus on job satisfaction (beta $=$ 0.622 ) and job satisfaction on turnover in- tention (beta $=-0.492)$. This results in an indirect effect of beta $=-0.306$. The standardized coefficient between the control focus on job satisfaction (beta $=-0.254)$ and job satisfaction on the turnover intention (beta= $-0.492)$ results in an indirect effect of beta= 0.746 .

To test the significance of the indirect effects, z-scores must be calculated using a Sobel test. The Sobel test calculates z-scores using the unstandardized coefficients and standard errors of both the commitment focus and control focus on job satisfaction, and job satisfaction on turnover intention. When the $z$-scores are higher than 1.96, it indicates a significant indirect relationship. The z-score for the indirect effect of commitment focus and turnover intention is $7.865>1.96$, and the $z$-score for the indirect effect of control focus and turnover intention is 5.001 $>1.96$. These results indicate that both indirect effects are significant, and so Hypothesis $3 \mathrm{~b}$ is confirmed.

Based on the analysis, in the absence of a direct relationship between HR attributions and turnover intention, the results show that the relationship between HR attributions and turnover intention is fully mediated (not partially mediated) via job satisfaction; this can be seen from the results showing a significant relationship between the independent variables (commitment focus and control focus) and the mediator (job satisfaction), a significant relationship between the mediator (job satisfaction) and the dependent variable (turnover intention), and a significant indirect relationship between $H R$ attributions and turnover intention. Therefore it can be concluded that HR attributions can predict the intention to leave through an employee's attitude, in this case the attitude of job satisfaction. This means when employees attribute certain HR practices, it does not directly in- 


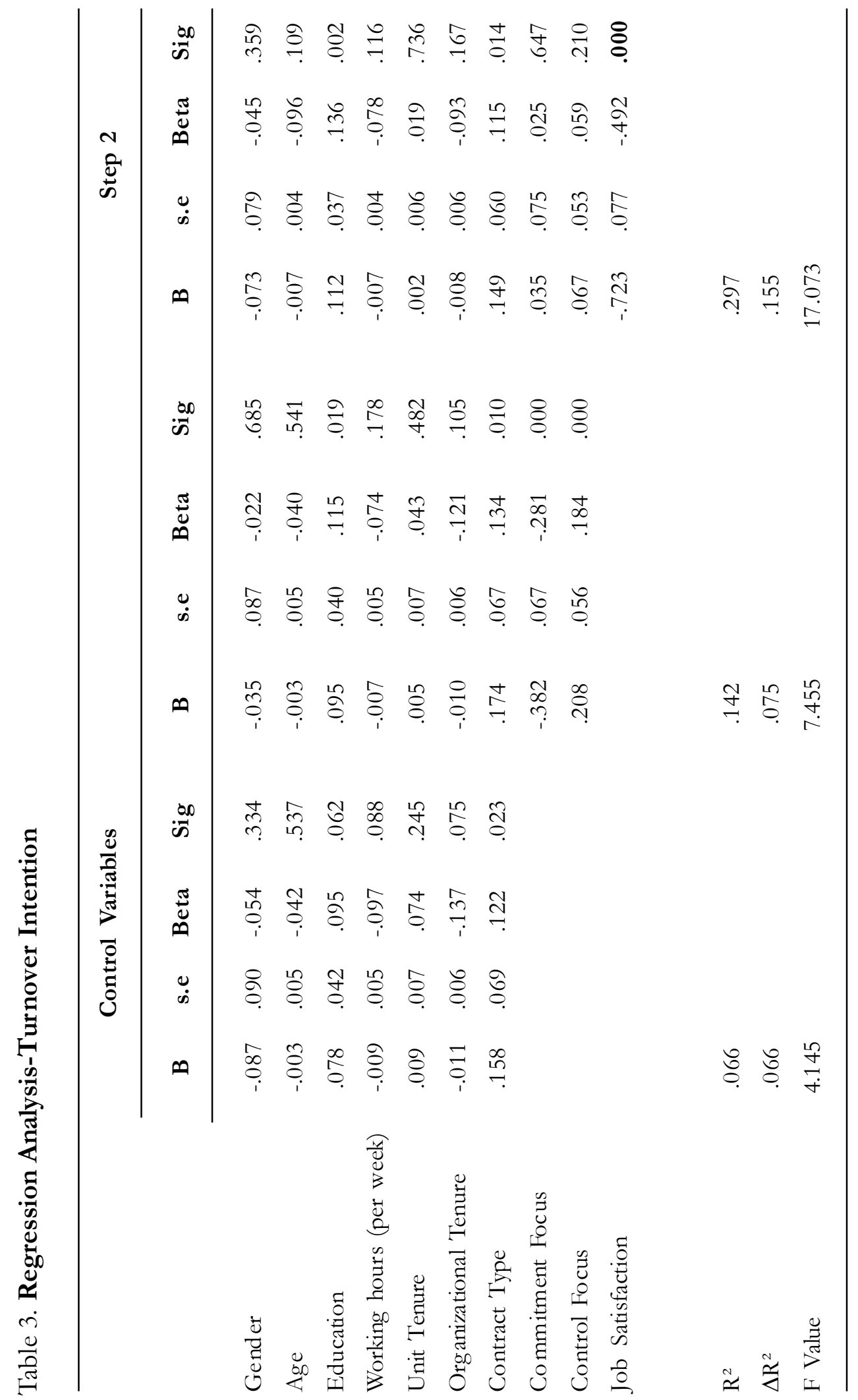


fluence their intention to quit, but it firstly goes through a psychological process in which their perception of certain HR practices triggers their attitudinal behavior: Job satisfaction. In turn, this attitudinal behavior, depending whether it is positive (satisfied) or negative (dissatisfied), will influence their intention to leave or to stay within the organization.

In comparison with previous studies, the HR attribution 'commitment focus' showed a high significant positive effect with job satisfaction which is consistent with the results of Nishii et al (2008), Nishii et al (2007), and Boselie and Wiele (2001) who indicate that when HR practices are perceived positively, they will result in an increase in the employees' job satisfaction. This study also confirms the work by Koster et al (2009); De Moura et al (2008); Boselie and Wiele (2001); Bowen and Ostroff (2000); Clark et al (1998); and Freeman (1978) that demonstrates a negative relationship between job satisfaction and turnover intention: A highly satisfied employee will have a lower tendency to leave the organization, and conversely a highly dissatisfied employee is more likely to leave the organization and change employer. Furthermore, the findings of this research are partly in line with the results by Chen and Wang (2014) whose study showed a partially mediated relationship between the HR attribution of commitment focus towards turnover intention, and a fully mediated relationship between the HR attribution of control focus towards turnover intention. Whereas the study of Chen and Wang (2012) examined the mediating role of affective commitment between HR attributions and turnover intention, this study examined the mediating role of job satisfaction.

Finally, this research has contributed the process-based approach by proving the impor- tance of the psychological process of employees in the HRM-perfor mance link. Where there is a concern that the role of HRM is starting to shift back to a strategy focus (van Buren III et al. 2011), the findings of this study indicate that employee focus is also of importance. Employees' perceptions and interpretations of HR practices should not be discarded but organizations should synchronize the intended and implemented HR practices as it is essential to understand the employees' reactions to HR practices (Piening et al 2014). As suggested by van Buren III et al. (2011), HRM professionals should champion both the management's and the employees' needs because they are of equal importance to achieving the organizational outcomes.

\section{Practical Recommendations}

When management is able to identify how their employees attribute HR practices, they can take the necessary actions to change their employees' perceptions to be more closely aligned with the management's ideal. As mentioned in Kelley (1967), Bowen and Ostroff (2004), and Piening et al (2014), the implementation of an effective HR system depends on the employees' view that the HR system fulfills the criteria of consistency, distinctiveness, and consensus. Therefore, in order for the employees to accurately perceive their management's intentions for their HR practices, the management must firstly deliver consistently clear messages/signals to the employees regarding the intentions of the HR practices, and ensure that these messages/ signals do not have contradictory meanings resulting in confusion.

Secondly, management should make sure that the employees understand how adopted HR practices work, in order to reduce multiple interpretations and misunderstandings. 
This in turn will make the HR practices distinct in the environment and may catch the employees' attention and trigger their interest.

Finally, whoever it is in management that delivers the messages/signals, the management team should be in agreement amongst themselves so that when the employees see that management (who are the decision makers) all agree on it, it can foster consensus between the employees. Moreover, as HR attributions can be seen as one of the roots or reasoning behind an employee's intention to leave, it is thus important to synchronize management's intentions and employees' perceptions.

\section{Limitations and Recommendations for Future Research}

The nature of this study is cross-sectional hence caution should be used when making assumptions or conclusions regarding the causality of the links between the factors. The causal relationships explored in this study could therefore be strengthened by extending the present cross-sectional analysis to a longitudinal study.

Furthermore, a possible limitation of this study is the shared perception between employees. Employees are usually nested within units or groups and these group-based relationships may affect the links between variables given the socialization process undergo ne by the individuals. Therefore employees' perceptions of HR practices may be influenced by other members of their unit, leading to the possibility of a distorted perception; a perception that is reached through the influence of the group members (Bliese
2000). Future research should hence measure the non-independence within such groups to get an estimation of how the individuals are affected by their group membership.

Future research can also incorporate individual factors such as personality and motivation (Chen and Wang 2014), as these factors may have an impact on the variables used in this study. Tests for other possibilities of mediation in terms of employee attitudes should also be looked into, such as employees' commitment and engagement, as these are also the antecedents of turnover intentions. Finally, similar studies on HR attributions can be conducted in different cultural settings (e.g. low context vs. high context cultures, collectivist vs. individualist cultures) as this will give additional insight into how an employee's cultural background may play a role in the HR attribution-turnover intention relationship.

\section{Conclusion}

The objective of this study was to contribute to the existing literature on the HRMperformance link by taking the standpoint of the process-based approach. The HR attribution typologies introduced by Nishii et al. (2008) were examined for the turnover intention to further prove the importance of the psychological process experienced by employees.

This research suggests that the relationship of HR attributions and turnover intentions is fully mediated through the variable job satisfaction. The findings imply that organizations should not only focus on their firms' strategic goals, but to also maintain an employee focus since employees' subjective interpretations of the HR practices may affect the organizational outcome. 


\section{References}

Arthur, J. B. 1992. The link between business strateg y and industrial relations systems in American steel mini mills. Industrial and Labor Relations Review 45 (3): 488-506.

Arthur, J. B. 1994. Effects of human resource systems on manufacturing performance and turnover. Academy of Management Journal 37: 670-687.

Blau, P. 1964. Exchange and power in social life. New York: Wiley.

Bliese, P. D. 2000. Within-group agreement, non-independence, and reliability: Implications for data aggregation and analysis In Klein K. J., and S. W. J. Kozlow ski (Eds.), Multilevel Theory, Research, and Methods in Organizations: Foundations, Extensions, and New Directions. 349-377. San Francisco: JosseyBass.

Boselie P., and V. A. Wiele. 2001. Employee perceptions of HRM and TQM and the effects on satisfaction and intention to leave. ERIM Report Series Research in Management. ERS-2001-42-ORG.

Boselie P., and V. A. Wiele. 2002. High performance work systems: 'Research on research' and the stability of factors over time. ERIM Report Series Research in Management. ERS-2002-44-ORG.

Bowen, D. E., and C. Ostroff. 2000. Moving HR to a bigher level: HR practices and organizational effectiveness. Multilevel Theory, Research, and Methods in Organizations: Foundations, Extensions, and New Directions: 211 256. San Francisco: Jossey-Bass.

Bowen, D. E., and C. Ostroff. 2004. Understanding HRM-firm performance linkages: The role of the "strength" of the HRM system. Academy of Management Review 29 (2): 203-221.

Chen, D., and Z. Wang. 2014. The effects of human resource attributions on employee outcomes during organizational change. Social Behavior and Personality 42 (9): 1431-1444.

Clark, A., Y. Georgellis, and P. Sanfey. 1998. Job satisfaction, wage changes and quitting: Evidence from Germany. Research in Labor Economics 17: 95-121.

Colarelli, S. M . 1984. Methods of communication and mediating processes in realistic job previews. Journal of Social Psychology 69 (4): 633-642.

De Moura, G. R., D. Abrams, C. Retter, S. Gunnarsdottir, and K. Ando. 2008. Identification as an organizational anchor: How identification and job satisfaction combine to predict turnover intention. European Journal of Social Psychology 39: 540-557.

Freeman, R. B. 1978. Job satisfaction as an economic variable, American Economic Review: Papers and Proceedings 68: 135-141.

Fontinha, R., M. J. Chambel, and N. De Cuyper. 2012. HR attributions and dual commitment of outsourced IT workers. Personel Review 41 (6): 832-848.

Guest, D. E. 2011. Human resource management and performance: Still searching for some answers. Human Resource Management Journal 21: 3-13.

Hilton, D. J., and B. R. Slugoski. 1986. Knowledge-based causal attribution: The abnormal conditions focus model. Psychological Review 93: 75-88.

Huselid, M. A. 1995. The impact of human resource management practices on turnover, productivity, and corporate financial performance. Academy of Management Journal 38 (3): 635-672.

Jackson, S. E., and R. S. Schuler. 1995. Understanding human resource management in the context of organizations and their environments. Anmual Review of Psychology 46: 237-264. 
Jaros, S. J. 1997. An assessment of Meyer and Allen's (1991) three-component model of organizational commitment and turnover intentions. Journal of Vocational Behavior 51: 319-337.

Jones M. K., R. J. Jones, P. L. Latreille, and P. J. Sloane. 2009. Training, job satisfaction, and workplace performance in Britain: Evidence from WERS 2004. Labour 23 (Special Issue): 139-175.

Kelley, H. H. 1967. Attribution theory in social psychology. In D. Levine (ed.), Nebraska Symposium on Motivation (Volume 15, pp. 192-238).

Kelley, H. H., and J. L. Michela. 1980. Attribution theory and research. Annual Review of Psychology 31: 457501.

Kim, S. 2012. The impact of human resource management on state government IT employee turnover intentions. Public Personnel Management 41 (2): 257.

Koster, F., A. de Grip, and D. Fouarge. 2009. Does Perceive Support in Employee Development Affect Personnel Turnover? Maastricht University RM/09/048.

Koys, D. J. 1988. Human resource management and a culture of respect: Effects of employees' organizational commitment. Employee Rights and Responsibilities Journal 1: 57-68.

Koys, D. J. 1991. Fairness, legal compliance, and organizational commitment. Employee Rights and Responsibilities Journal 4 (4): 283-291.

Kroon, B., K. van de Voorde, M. van Veldhoven. 2009. Cross-level effects of high-performance work practices on burnout. Personel Review 38 (5): 509-525.

Locke, E. 1976. Nature and causes of job satisfaction. In M. D. Dunnette (Ed.), Handbook of Industrial and Organizational Psychology. Chicago: Rand McNally.

Lord, R. G., and J. E. Smith. 1983. Theoretical, information processing, and situational factors affecting attribution theory models of organizational behavior. Academy of Management Revien 8 (1): 50-60.

MacKinnon, D. P., A. J. Fairchild, and M. S. Fritz. 2007. Mediation analysis Annual Review of Psychology 58: 593-614.

Mahdi, A. F., M. Z. M. Zin, M. R. M. Nor, A. A. Sakat, A. S. A. Naim. 2012. The relationship between job satisfaction and turnover intention. American Journal of Applied Sciences 9 (9): 1518-1526.

Mbah, S. E., and C. O. Ikemefuna. 2012. Job satisfaction and employees' turnover intentions in total Nigeria plc. in Lagos state. International Journal of Humanities and Social Science 2 (14).

Mitchel, J. O. 1981. The effect of intentions, tenure, personal, and organizational variables on managerial turnover. Academy of Management Journal 24 (4): 742 - 751.

Nishii, L. H., and P. M. Wright. 2007. Variability within organizations: Implications for strategic human resource management. Center for Advanced Human Resource Studies (CAHRS) Working Paper Series 1-12007.

Nishii, L. H., D. P. Lepak, and B. Schneider. 2008. Employee attributions of the "why" of HR practices: Their effects on employee attitudes and behaviors, and customer satisfaction. Personnel Psychology 61 (3): 503-546.

Park, H. Y., J. Ofori-Dankwa, and D. B. Ramirez. 1994. Organizational and environmental determinants of functional and dysfunctional turnover: Practical and research implications. Human Relations 47: 353-367.

Piening, E. P., A. M. Baluch, and H-G. Ridder. 2014. Mind the intended-implemented gap: understanding employees' perceptions of HRM. Human Resource Management 53 (4): 545-567. 
Saeed, I., M. Waseem, S. Sikander,and M. Rizwan. 2014. The relationship of turnover intention with job satisfaction, job performance, leader member exchange, emotional intelligence and organizational commitment. International Journal of Learning and Development 4 (2). DOI: 10.5296/ijld.v4i2.6100.

Sanders, K., and H. Yang. 2015. The HRM process approach: The influence of employees' attribution to explain the HRM-performance relationship. Wiley Periodicals, Inc. DOI: 10.1002/hrm.21661.

Schwab, D. P. 1991. Contextual variables in employee performance-turnover relationships. Academy of Management Journal 34: 966-975.

Spector, P. E. 1997. Job Satisfaction: Application, Assessment, Causes, and Consequences. Thousand Oaks, California: Sage Publications, Inc.

Subramony, M. 2009. A meta-analytic investigation of the relationship between HRM bundles and firm performance. Human Resource Management 48: 745-768.

Tsui, A. S., J. L. Pearce, L. W. Porter, and A. M. Tripoli. 1997. Alternative approaches to the employeeorganization relationship: Does investment in employees pay off? Academy of Management Journal 40 (5): 1089-1121.

van Buren III, H. J., M. Greenwood, and C. Sheehan. 2011. Strategic human resource management and the decline of employee focus. Human Resource Management Review 21: 209-219.

Vandenberg, R. J., and J. B. Nelson. 1999. Disaggregating the motives underlying turnover intentions: When do intentions predict turnover behavior? Human Relations 52: 1313-1336.

Vroom, V. H. 1966. Organizational choice: A study of pre- and post-decision processes. Organizational Behavior and Human Performance 1: 212-225.

Wang, Y. D., C. Yang, and K. Y. Wang. 2012. Comparing public and private employees' job satisfaction and turnover. Public Personnel Management 41 (3): 557.

Wanous, J. P., A/ E. Reichers, and M. J. Hudy. 1997. Overall job satisfaction: How good are single-item measures? Journal of Applied Psychology 82 (2): 247-252.

Wright, P. M., G. C. McMahan and A. McWilliams. 1994. Human resources and sustained competitive advantage: A resource-based perspective. International Journal of Human Resource Management 5: $301-$ 326. 
